\title{
The Ebola Epidemic and Cholera Outbreak and The International Response
}

\author{
RICHARD B. ROBERTS
}

\begin{abstract}
Infectious diseases are responsible for 15 million of the 57 million deaths worldwide despite the remarkable discoveries of antibiotics and vaccines. Many individuals succumb to microbial diseases in poor and less-developed countries where these preventive and therapeutic modalities are not available. Furthermore these less fortunate countries do not have the resources or public health infrastructure to combat unforeseen and explosive outbreaks. Two relatively recent outbreaks are reviewed in this article; the Ebola epidemic in West Africa and the cholera outbreak in Haiti. This outbreak of cholera, in a country of only 7.8 million inhabitants, is one of the largest ever recorded worldwide. Early intervention by international health organizations is critical to curtail and ultimately control infectious disease outbreaks and epidemics. This responsibility, especially for less-developed countries, lies in the hands of the United Nations and World Health Organization. Unfortunately, the international response from the UN and WHO was slow, cumbersome and poorly coordinated both in West Africa and Haiti.
\end{abstract}

Keywords: $\bullet$ Ebola $\bullet$ Cholera $\bullet$ international respons $\bullet$ United Nations

- World Health Organization

CORRESPONDENCE ADDRESS: Richard B. Roberts, M.D. Rockefeller University, Laboratory of microbiology, Box 152, 1230 York Avenue, NY 10065, New York, USA, e-mail: barg@ rockefeller.edu. 
R. B. Roberts: The Ebola Epidemic and Cholera Outbreak and The International Response

Microbial species constitute $60 \%$ of the earth's biomass and preceded animals and plants by more than three billion years. Less than $0.5 \%$ of the estimated $2-3$ billion microbial species have been identified though relatively recent microbial genomics will undoubtedly increase the number. This is compared to approximately 5400 species of mammals. Fortunately to date, only a minute fraction of all microbial species are potential pathogens for the human host. Yet infectious diseases are responsible for 15 million of the 57 million annual deaths (26\%) in a global population of 6.2 billion people.

Characteristics that set infectious diseases apart from other human diseases are listed in Table 1 (Fauci \& Morens, 2012). Most important relative to emerging infections are the potential for unpredictable and explosive impact, transmissibility, highly adaptable pathogens with rapid replication and mutation, and frequent derivation and coevolution in other animal species. Indeed, emerging microbial diseases have captured the imagination of the lay public for decades, as exemplified in film portrayals. The Andromeda Strain (1971), Outbreak (1995) and Contagion (2011) are just a few examples. Most often in these films, when a mysterious disease emerges, it is investigated and controlled. However in real life, we live in an ecological complex world where real and lethal microbial diseases occur. Most emerging infections do not disappear forever but will reemerge due to the susceptibility of the population, microbial mutation that changes its virulence, transmission capability, and persistence of the microbe in nature (often referred to as "remaining hidden"). For example, bats, that account for $25 \%$ of all mammalian species are important reservoirs in nature (infectious but not ill) for emerging zoonotic infections (EZI). These animals are abundant throughout the world, often residing in caves where they remain exceedingly social. This sociability accounts for an "epizootic cycle" in which many animals infected at the same time leads to human exposure and infection ("spillover"). Examples of bat reservoirs for viral EZI include rabies worldwide, Nepah virus in Malaysia, Hendra virus in Australia, SARS-CoV in China, MERS-CoV on the Arabian Peninsula and Marburg and Ebola viruses in Africa (Quammen 2014). Additional factors that contribute to the emergence of infectious diseases are listed in Table 2 (Morens, Folkers \& Fauci, 2008).

To date, approximately 175 emerging pathogens have been described of which $75 \%$ are zoonotic in origin. In the past two decades more than 30 new zoonotic infections have emerged, the majority of which have been RNA viruses. More than 500 RNA viruses have been identified in the past of which approximately 100 are human pathogens. RNA viruses possess unique properties that allow them to emerge including high variability (mutations), rapid adaptation to a changing environment, the ability to cross species barriers, rapidly serve as reservoirs and be sentinel events (precede infections in humans) and may be transmitted by vectors or directly from 
animals to humans. Facilitators for emerging RNA viral diseases are listed in Table 3. For these reasons, RNA viruses continue to appear in previously naïve geographic settings. A partial list of recent outbreaks and epidemics due to RNA viruses are in Table 4.

Early intervention by international health organizations is critical to curtail and ultimately control infectious-disease outbreaks and epidemics. This responsibility and leadership, especially for less-developed countries, lies in the hands of the United Nations (UN) and its Specialized Agency in Health, The World Health Organization (WHO). Other international programs such as Doctors Without Borders and Partners in Health also play an important role. The following is a brief review of a recent epidemic and outbreak-Ebola Virus Disease in West Africa and Cholera in Haiti-and the international response.

\section{Ebola Virus Disease in West Africa}

There are five distinct species of Ebola viruses. The names are based on the geographic location where first identified. Ebola Virus Disease (EVD) was first reported in 1976 in both the Democratic Republic of Congo (DRC) near the Ebola River (Zaire virus) and in South Sudan (Sudan virus). The second Zaire Ebolavirus (EBOV) outbreak was 18 years later in Gabon. From 1976-2014, there were 25 discrete outbreaks in the following African countries; DRC, Sudan, Gabon, Uganda and the Republic of Congo (DOC). Thirteen outbreaks were caused by the Zaire virus and six by the Sudan virus. The total number of reported cases was 2,368 with 1,590 deaths (67\% mortality). In most instances EVD emerged in remote regions that were geographically restricted and outbreaks were contained through routine public health measures that included education, hygienic practices, case identification, contact tracing, patient isolation and quarantine in order to break the chain of transmission (Breman \& Johnson, 2014; Fauci, 2014).

The West African epidemic of EVD (Zaire virus) was first reported to WHO from Guinea on March 21, 2014. However in retrospect, the initial case was probably a two-year-old boy exposed to bats while playing in a hollow tree on December 6 , 2013 (Mari Saez et al., 2015). The EBOV then spread from Guinea to Liberia and in May to Sierra Leone. By December 15, 2014, nine months later, 17,908 cases with 6,533 deaths had been reported from these three countries. On December 17, the UN Secretary General Mr. Ban Ki-moon announced he would visit West Africa. He had planned to visit the Ebola-affected countries earlier but his aides said it had been difficult to include that trip in an already busy travel schedule. By February $10,2015,23,859$ cases were reported (13,955 confirmed) with 9,162 deaths. However estimates suggested that for every 100 reported cases 125 went unrecognized. This was the first Ebola outbreak in West Africa and the largest Ebola outbreak in history. 
Factors that facilitated the spread of EVD in West Africa are listed in Table 5. In addition, a recent study suggests that a single amino acid change in the virus glycoprotein may have made the West African Ebola virus more virulent (Bedford \& Malik, 2016). Human to human transmission of the Ebola virus was contact with broken skin or mucous membranes with bodily fluids (blood, saliva, sweat, urine, stool or semen) as well as objects such as needles contaminated with these bodily fluids. Thus transmission occurred quickly within families, at funerals and in hospitals and clinics. Indeed, $60 \%$ of initial cases were linked to traditional burials since local customs included bathing of corpses before burial. By May 10, 2015, 26,648 cases of EVD had been reported with 11,007 deaths (overall mortality 41\%) at which time WHO declared Liberia free of EVD, 42 days after the last burial. Over the year that followed the initial outbreak in the spring of 2014, many articles were written detailing the horrific morbidity and mortality in patients infected with EVD in the three West African countries (Bah et al., 2015, Chertow et al., 2014, Schieffelin et al., 2014).

The International Response

The international response from the UN and WHO was slow, cumbersome and poorly coordinated (Sands, Mundaca-Shah \& Dzau, 2016). The EVD outbreak in Guinea became evident to on-site health care workers with Doctors Without Borders and first reported to WHO on March 21, 2014 followed by reports from the peacekeeping mission in Liberia to the UN on March 24. Thereafter both caretakers sent multiple communications voicing their concerns to the UN and WHO. Both organizations have denied they received these communications. Despite the rising death toll and spread of the disease to Liberia and Sierra Leone, Dr. Margaret Chan, Director General of WHO did not declare the epidemic to be a Public Health Emergency of International Concern (PHEIC) until August 8, 2014 (Briand et al., 2014). By that time more than 1000 Africans had died of EVD. The declaration by Dr. Chan was initiated by a single symptomatic patient who traveled by air from Monrovia Liberia to Lagos Nigeria and was the index case for an additional twelve infected patients. However transmission was quickly prevented in Nigeria. This late global response by Dr. Chan for more than four months may have been partially responsible for the widespread and intense epidemic of EVD throughout the three West African countries (Farrar \& Piot, 2014). On October 30, 2014, almost three months after PHEIK was declared, Dr. Chan publically admitted that "the scale of the response did not match the scale of the outbreak" (Walt, 2014). Of note, only WHO can declare a global health emergency. WHO officially declared the PHEIC over March 29, 2016.

Unfortunately, under Dr. Chan's tenure as Director General, local governments steered the agency in Geneva to fit their own needs including WHO's regional offices in West Africa which were effectively controlled by their governments. As a result, each African country's regional head was appointed not by WHO but by 
his respective government often based on political connections and not public health expertise. In addition, regional offices were not supervised by WHO in Geneva. For example, the Liberian WHO representative reassured UN colleagues that "the virus would subside". Furthermore, the UN stated that "WHO primarily provides technical support, not service". In September 2014, Dr. Chan defended her position by stating "We (WHO) are not first responders" and attributed the magnitude, severity and containment difficulty to "a single word: poverty" (Chan, 2014). In very poor West African countries with limited resources, public health infrastructure and medical care by health professionals, this author asks-Who then should be the first international responders? Clearly the first responder in the initial West African outbreak was Doctors Without Borders.

Some corrective measures were instituted by WHO in January 2015. Dr. Matshidiso Moeti from Botswana, a well-respected physician who had run the TB and HIV programs in that country, was appointed the new regional director for Africa and she promised competence tests and audits of job performance by outside reviewers. Also in January, the executive board of WHO recommended that the World Health Assembly (composed of a member from each of the 194 countries) approve the following institutional reforms; a global cadre of well-trained public health workers, regional staff members be appointed with public health expertise, and a $\$ 100$ million emergency fund be created to support these initial efforts. In May 2015, an expert panel at the annual World Health Assembly meeting recommended for WHO "a structural reform and radical change in culture".

A discussion of the EVD epidemic in West Africa would not be complete without paying tribute to those health care workers $(\mathrm{HCW})$ who risked their lives to care for the ill. $5300 \mathrm{HCW}$ with Doctors Without Borders participated in the care of patients; 28 became infected with EBV and 14 died. These volunteers had first-hand knowledge of the human suffering and many have chronicled their personal accounts of the tragic events that took place in West Africa (Antierens et al., 2017). Additional HCW who had also volunteered and contracted EVD were transferred to Great Britain, Spain, Germany, Italy and the United States for observation and treatment. But we should never forget that $825 \mathrm{HCW}$ from West Africa became infected and 493 died of the disease. Many were leading physicians in their respective countries (Mugele \& Priest 2014). These individuals are the unsung heroes in this tragic epidemic.

\section{$4 \quad$ Cholera in Haiti}

WHO estimates that 1.5 billion people are at risk for cholera worldwide. The annual global burden is 3 million to 5 million cases with 100,000-120,000 deaths. Cholera is endemic in South Asia and Africa and outbreaks may occur in both endemic and epidemic geographic areas. Infection is often a result of man-made or natural disasters, especially if refugees are living in overcrowded and unsanitary conditions. 
Cholera is a disease of poverty and occurs due to a lack of potable (clean) water, adequate hygiene, proper sanitation and adequate medical facilities.

Haiti, a country with 7.8 million inhabitants, is the poorest nation in the Western Hemisphere. The average income is \$2US/day; $80 \%$ of people are either unemployed or underemployed. The country has the worst water security in this hemisphere. Almost a decade before the 2010 earthquake, Haiti ranked last out of 147 countries in the Water Poverty Index (a measure of water security) (Walton and Ivers 2011). Only $27 \%$ of the country has basic sewage and $70 \%$ of households have rudimentary or no toilets. Thus waterborne pathogens (such as typhoid, intestinal parasites and bacteria dysentery) and fecal-oral transmission are common.

On January 12, 2010 Port-au-Prince, the capital of Haiti was the epicenter of a catastrophic earthquake that devastated the nation's capital and southern towns, leaving 250,000 people dead and an additional 300,000 severely hurt, mostly from crush injuries. Three million inhabitants were displaced, 1.3 million were left to live in 1,356 unsanitary refugee camps and an additional 182,000 were displaced to the countryside (Pape, Johnson \& Fitzgerald, 2010; Walton \& Ivers, 2011). Over the subsequent months, many experts warned of a potential epidemic disease outbreak.

During the first week of October 2010, several thousand Nepalese arrived in the Artibonite countryside (Rural Center Department of Haiti), approximately 62 miles north of the capital, for a United Nations peace-keeping mission. Soon after arrival, Haitians complained of black sludge in the water supply along a tributary of the Artibonite River that bordered the UN military base. The waste came from the base outhouses and overflowed from broken pipes that contaminated the River. Water from the River was used by Haitians for drinking as well as bathing and washing. The first case of cholera was reported on October 20, 2010, ten months following the earthquake. Three weeks later, on November 8, 2010, Hurricane Tomas struck Haiti causing flooding and worsening conditions in the already inhumane refugee camps. By February 4, 2011, 216,000 cases of cholera were reported across all ten departments with 4,131 deaths. However, Doctors Without Borders reported that cholera mortality in the first two years of the outbreak was substantially higher than the official count (Luquero et al., 2016). Over the next two years, 604,634 cases were reported with 329,697 hospitalizations and 7,436 deaths accounting for more than $50 \%$ of all cholera cases worldwide (Barzilay et al., 2013). By November 21, 2014 , four years after the first reported case, 717,203 patients had become infected ( $10 \%$ of the country's population), 404,371 were hospitalized and 8,721 died. This outbreak of cholera in Haiti was one of the largest ever recorded worldwide. The outbreak is yet another example of how cholera can become endemic, spread through a susceptible population and rapidly kill its victims within hours from the onset of symptoms. 
Tragically the cholera outbreak in Haiti is still continuing seven years later. In 2015, Haiti reported more cases of cholera per population than any other country. In the first nine months of 2016, 29,000 new cases were recorded, even before Hurricane Matthew devastated Haiti's southern peninsula in October of that year (Ivers, 2017).

Cholera had been present in Latin America since it was introduced into Peru in 1991 but had not been reported in Haiti for at least 100 years. Research studies demonstrated that the toxigenic Vibrio cholerae strain responsible for the outbreak in Haiti was clonal and related to the variant serogroup 01, biotype El Tor, serotype Ogawa previously unknown in the Western Hemisphere (Chin et al., 2011; Talkington et al., 2011). This strain had recently been isolated from South Asia including Bangladesh and Nepal as part of an ongoing Seventh Cholera pandemic. The Haitian strain also appeared to have a higher relative fitness, an increased antibiotic resistance and virulence which explains in part the initial higher mortality compared to outbreaks in South Asia and Africa (Ceccarelli et al., 2011; Walton \& Ivers, 2011).

\section{The International Response}

Partners in Health, the international medical aid organization has had a longstanding commitment to the health of the Haitian people. Between October 20 and November 9, 2010 they recorded 7,159 cases of severe cholera; 161 of these patients died in seven of its hospitals in the Central and Artibonite regions (Walton \& Ivers, 2011). Doctors Without Borders was also among the first medical aid groups to assist the Haitian government in assessing and treating patients with cholera that had spread nationwide within the month (Walton and Ivers 2011). Initially, UN officials argued against investigating the source of the outbreak. A spokesman for WHO said that finding the cause of the outbreak was "not important". Nepal's representative to the UN "categorically refuted" the hypothesis that Nepali peacekeepers were responsible. Various alternate hypotheses put forth by the UN and WHO included Haiti's poverty, the climate and the earthquake. Furthermore the UN deterred epidemiologists from tracing the origin of the epidemic, and Nepalese peacekeepers removed the broken pipes that connected the camp's latrines to the stream below. Some believe this was an attempt to hide evidence of the source of the outbreak. However Paul Farmer, a co-founder of Partners of Health and President Clinton's No. 2 at the Office of Special Envoy for Haiti argued that there was no reason to wait and under intense pressure the UN relented and ultimately appointed a panel to investigate the source of the cholera strain. Meanwhile as early as 2011, both epidemiologic and scientific studies clearly demonstrated that the source was from sewage waste from the Nepalese camp and the strain was the same as that responsible for the ongoing outbreak in Nepal (Chin et al., 2011; Piarroux et al., 2011). Despite this evidence, the UN refused to take responsibility for its role in the initiation and spread of the disease. As late as April 2012 a spokesman for the UN's 
R. B. Roberts: The Ebola Epidemic and Cholera Outbreak and The International Response

Secretary General said publicly it was not possible to conclude how cholera arrived in Haiti.

To make matters worse, the families of cholera victims petitioned the UN for redress but its Office of Legal Affairs declared their claims "not receivable". A class-action suit was then filed in the federal court of New York against the UN and the Secretary General. The UN refused to appear at court hearings claiming "absolute" diplomatic immunity under its charter. In August 2016, the US federal appeals 3-judge panel upheld the argument that the UN could not be sued in American courts by the classaction lawsuit brought on behalf of the thousands of cholera victims in Haiti.

In August 2016, six years after cholera was introduced into Haiti, Mr. Ban acknowledged that the UN played a role in the initial outbreak but stopped short of saying that the UN specifically caused the epidemic and avoided any mention of who brought cholera to Haiti. His statement was in response to a confidential report sent to Mr. Ban by a longtime UN advisor on August 8 and was presented to the General Assembly in September. The 19 page report that was made available to the New York Times was written by Mr. Philip Alston, a New York University law professor who advises the UN on internal human rights issues (Katz, 2016). He stated that the epidemic "would not have broken out but for the actions of the UN". He also wrote that the UN's Haiti cholera policy was "morally unconscionable, legally indefensible and politically self-defeating". The organization's continuing denial and refusal to make reparations to the victims he argued "upholds a double standard according to which the UN insists that member states respect human rights, while rejecting any such responsibility itself". He said "It provides highly combustible fuel for those who claim that UN peacekeeping operations trample on the rights of those being protected, and it undermines both the UN's overall credibility and the integrity of the office of the Secretary General". In blaming the entire UN system he said "As the magnitude of the disaster became known, key international officials avoided acknowledging that the outbreak had resulted from discharges from the camp". Mr. Alston's most severe criticism however was reserved for the UN's Office of Legal Affairs whose advice "has been permitted to override all the other considerations that militate so powerfully in favor of seeking a constructive and just solution. Its interpretations have trumped the rule of the law".

In December 2016, weeks before the end of his ten-year tenure as Secretary General, Mr. Ban announced a "New Approach" by the UN towards Haiti's outbreak that will include a $\$ 400$ million trust fund, \$200 million for cholera eradication and improved sanitation and \$200 million for "material assistance" to families and communities most affected. Dr. David Nabarro, one of the three candidates for Director General of WHO, a British physician and recently appointed by Mr. Ban to lead the anti-cholera effort has said that "most people recognize this is something the UN has to deal with. It's an unfinished story. That does not obviously translate 
immediately into money". The UN's years of silence and denial of its responsibility may well impede its efforts to launch an effective response to the cholera outbreak.

\section{Summary-"Expect the Unexpected"}

As so amply demonstrated by the Ebola and cholera reports outlined above, infectious-disease outbreaks and epidemics may appear without warning and be explosive in magnitude. They can be associated with enormous suffering and mortality as we witnessed with these two outbreaks. They are extremely difficult to curtail in very poor countries such as West Africa and Haiti because of many factors including inadequate public health infrastructure. Thus, early intervention by the international community, specifically a timely response, leadership and coordination by the UN and WHO is paramount to the success of control efforts. So what will the humanitarian response be for the next infectious-disease outbreak? I am relatively optimistic. First, because there will be a change in leadership. The tenyear tenures for the UN Secretary General and WHO Director General come to a close in 2017. In January, Mr. Antonio Guterres, a former prime minister of Portugal became the new Secretary General. He had directed the UN's refugee agency for ten years and may be more sympathetic to the underserved than his predecessor. In April 2017, upon the recommendation of Mr. Guterres, the UN Security Council unanimously voted to end the 13 year-long peacekeeping mission in Haiti. In May 2017, Dr. Tedros Adhanom Ghebreyesus, who goes by his first name and one of three candidates for WHO Director General was elected on May 23, the first African to head the agency. He holds a $\mathrm{PhD}$ in community health. He was Ethiopia's health minister from 2005 to 2012 and foreign minister from 2012 to 2016. During his tenure as health minister, he trained 40,000 female health workers, improved national laboratories, created an ambulance system and increased medical graduates ten-fold. Deaths from AIDS, tuberculosis and malaria as well as deaths in young children and women in childbirth fell by more than 50 percent. However, Dr. Tedros has been accused of taking steps to cover up Ethiopia's long history of cholera outbreaks $(2006,2009,2011)$, calling them "acute watery diarrhea" and the health ministry refused to test specimens for $V$. cholerae. He has also been accused of complicity in his country's terrible human rights record. He has denied both accusations. On May 21, 2017 just prior to his election, the Associated Press, based on WHO internal documents, reported that staff members who live on tax-free UN salaries in Switzerland routinely disregard travel rules and spend \$200 million of WHO's $\$ 2.2$ billion annual budget on travel (flying business class and staying in five star hotels), a sum that exceeds that spent for programs to prevent and treat diseases such as AIDS, tuberculosis and malaria, the major causes of infectious disease deaths worldwide. Indeed, the Global Fund to Fight AIDS, Tuberculosis and Malaria, which raises about $\$ 5$ billion a year, has become the main conduit for fighting these diseases. Dr. Tedros has promised to make WHO more accountable and transparent in hopes of restoring the organization's global credibility and respect. Secondly, efforts have been initiated to strengthen the public health 
infrastructure in the West African countries and Haiti. The executive board of WHO has proposed the institutional reforms outlined above including the $\$ 100$ million emergency fund to support the initial efforts. Prior to leaving the UN, Mr. Ban announced a "New Approach" for efforts in Haiti that included the \$400 million trust fund. However, both programs will fall on the shoulders of the new leadership and will depend on the cooperation and willingness of donor countries to contribute the necessary funds. Indeed, this may not be an easy task during this time of economic and political instability throughout the world. By April 2017, four months after Mr. Ban announced his proposal, only $\$ 2.66$ million had been donated from six of the 194 member states. To date, the United States has not contributed to the effort though in the past has been the major financial contributor to UN efforts, funding $28 \%$ of its $\$ 7.87$ billion budget. On March 16, 2017, the newly elected President of the United States submitted his budget titled "America First" with a proposal to cut the 2018 National Institutes of Health (NIH) budget by $18.3 \%$ including the elimination of the Fogarty International Center whose $\$ 69.2$ million budget funds international programs and has the smallest budget among the NIH's 27 institutes and centers (Katz \& Wright, 2017; Drain, Subbaraman \& Heimburger 2017). Thirdly, it has become clear that safe, effective and low cost vaccines must play a pivotal role in the control of future explosive epidemics. However vaccine development takes time and vaccines are not available until the unexpected outbreak has subsided. Vaccines were not available during the initial outbreaks of either Ebola or cholera. However two vaccines for Ebola have now been successfully tested for immunogenicity and safety though their clinical efficacy is still unknown (Bausch, 2017; Ledgerwood et al., 2017; Regules et al., 2017). Two oral vaccines are now available for cholera though the vastly cheaper one is made in India and has yet to be approved by WHO (Ivers, 2017; Pape \& Rouzier, 2014). Paul Farmer and others have strongly recommended a stockpile of millions of doses of the cholera vaccine for future outbreaks as is done now with the measles vaccine (Waldor, Hotez \& Clemens, 2010). But what about the availability of vaccines for future unpredictable infectious-disease outbreaks -- expect the unexpected. At the January 2017 World Economic Forum meeting a group of prominent donors announced the formation of the Coalition for Epidemic Preparedness Innovations (CEPI) "to stimulate, finance and coordinate the development of vaccines for epidemic diseases". Almost $\$ 500$ million have been raised to support this global partnership (Roberts, 2017).

As time passes, let us never forget the horrific epidemic of Ebola in West Africa, the tragic outbreak of cholera that continues to this day seven years later in Haiti, and the human suffering that has occurred in these poor and less-developed countries. As David Quammen wrote in his book, EBOLA. The Natural and Human History of a Deadly Virus-published in September 2014 at the height of the epidemic in West Africa: 
"What we should recognize, what we should remember, is that events in West Africa (so far) tell us not just about the ugly facts of Ebola's transmissibility and lethality; they tell us also about the ugly facts of poverty, inadequate health care, political dysfunction, and desperation in three West African countries, and of the neglectful disregard of those circumstances over time by the international community."

\section{Appendix}

Table 1. Characteristics that set infectious diseases apart from other human diseases

Potential unpredictable and explosive global impact

Frequent durable host immunity against reinfection

Disease by a single agent (multiple cofactors not required)

Transmissibility

Potential for becoming preventable

Potential for eradication

Highly adaptable pathogens-replication and mutation

Close dependence on nature of human behavior

Frequent deviation and coevolution with animal species

Secondary treatment effects on preventing infection in contacts, community and microbial and animal ecosystems

(Fauci \& Morens, 2012)

Table 2. Factors in the Emergence of Infectious Diseases

International trade and commerce

Human demographics and behavior

Human susceptibility to infection

Poverty and social inequality

War and famine

Breakdown of public health measures

Technology and industry

Changing ecosystems

Climate and weather

Intent to harm

Lack of political will

Microbial adaptation and change

Economic development and land use

(Morens, Folkers \& Fauci, 2008)

Table 3. Facilitators for Emerging RNA Viral Diseases

Human encroachment on previous isolated habitats

Global warming producing shifts in ecosystems for vectors and hosts

Inadvertent rapid global transportation of vectors and hosts

Exposure of immunologically vulnerable populations 
R. B. Roberts: The Ebola Epidemic and Cholera Outbreak and The International Response

\begin{tabular}{|c|c|c|c|}
\hline \multicolumn{2}{|c|}{ Table 4. RNA viruses associated with outbreaks and epidemics in recent years } \\
\hline $\begin{array}{c}\text { Mode of } \\
\text { transmission }\end{array}$ & RNA virus & Year (location) & Reference \\
\hline Airborne (respiratory) & Influenza A & 2009 (global) & (Glezen, 2010) \\
\hline & SARS-CoV & $\begin{array}{c}2003 \text { (Hong Kong, } \\
\text { global) }\end{array}$ & $\begin{array}{c}\text { (Donnelly et al., } \\
2003)\end{array}$ \\
\hline & MERS-CoV & 2012 (Arabian & $\begin{array}{c}\text { (Arabi et al., } \\
2017)\end{array}$ \\
\hline Vector (arthropod) & Peninsula) & $\begin{array}{c}\text { (Brown \& } \\
\text { DeMaria, 2012) }\end{array}$ \\
\hline & CHIKV & 1999 (United States) & $\begin{array}{c}\text { (Weaver \& } \\
\text { Lecuit, 2015) }\end{array}$ \\
\hline & Zika virus & 2005 (Indian Ocean) & $\begin{array}{c}\text { (Staples \& } \\
\text { Fischer, 2014) }\end{array}$ \\
\hline & & 2013 (Caribbean) & $\begin{array}{c}\text { (Cao-Lormeau et } \\
\text { al., 2014) }\end{array}$ \\
\hline & Yellow fever & 2013 (Polynesia) & (Petersen et al., \\
& & $2016)$ \\
\hline
\end{tabular}

SARS-CoV=Severe Acute Respiratory Syndrome; MERS-CoV=Middle East Respiratory Syndrome; CHIKV=Chikungunya virus

Note: AIDS was first described in 1981 and the human immunodeficiency virus (HIV) identified in 1984.

Table 5. Factors that facilitated the spread of EBV in West Africa

Poor nations with limited public health infrastructure

Emergence in heavily populated capitals (Conakry, Monrovia, Freetown)

No prior experience with Ebola virus disease

Few health care professionals (1-2 MD per 100,000 population)

Countries with multiple communicable diseases-malaria, typhoid fever, Lassa fever, Yellow fever, cholera

Frequent travel across porous borders

Limited cooperation between adjacent governments

History of regional conflicts and political distrust

Fear of health care workers and hospitals (50\% of admissions died)

Fear leading to panic

\section{Acknowledgment:}

The author is very grateful to Helen Curry for her assistance in the preparation of this manuscript. 


\section{References}

Antierens, A., A. Benton, J-F. Caremel, P. Carrick, A. Desclaux, M. Diop, S. Doyon, S.L.B. Faye, L. Hurum, T. Kratz, P. Lahai, A.T. Lappia, D. McLean, J. Nunes, T. O'Dempsey, R. Ouedraogo, M. Philips, A. Rid, M. Santantonio \& A. Sprecher (2017) The Politics of Fear. Médecins sans Frontières and the West African Ebola Epidemic (Oxford, United Kingdom: Oxford University Press).

Arabi, Y. M., H. H. Balkhy, F. G. Hayden, A. Bouchama, T. Luke, J. K. Baillie, A. Al-Omari, A. H. Hajeer, M. Senga, M. R. Denison, J. S. Nguyen-Van-Tam, N. Shindo, A. Bermingham, J. D. Chappell, M. D. Van Kerkhove \& R. A. Fowler (2017) Middle East Respiratory Syndrome, The New England Journal of Medicine 376(6), pp. 584-594, doi: 10.1056/NEJMsr1408795.

Bah, E. I., M. C. Lamah, T. Fletcher, S. T. Jacob, D. M. Brett-Major, A. A. Sall, N. Shindo, W. A. Fischer, 2nd, F. Lamontagne, S. M. Saliou, D. G. Bausch, B. Moumie, T. Jagatic, A. Sprecher, J. V. Lawler, T. Mayet, F. A. Jacquerioz, M. F. Mendez Baggi, C. Vallenas, C. Clement, S. Mardel, O. Faye, O. Faye, B. Soropogui, N. Magassouba, L. Koivogui, R. Pinto \& R. A. Fowler. (2015) Clinical presentation of patients with Ebola virus disease in Conakry, Guinea, The New England Journal of Medicine, 372(1), pp. 40-47, doi: 10.1056/NEJMoa1411249.

Barzilay, E. J., N. Schaad, R. Magloire, K. S. Mung, J. Boncy, G. A. Dahourou, E. D. Mintz, M. W. Steenland, J. F. Vertefeuille \& J. W. Tappero (2013). Cholera surveillance during the Haiti epidemic--the first 2 years, The New England Journal of Medicine, 368(7), pp. 599-609, doi: 10.1056/NEJMoa1204927.

Bausch, D. G. (2017) One Step Closer to an Ebola Virus Vaccine, The New England Journal of Medicine, 376(10), pp. 984-985, doi: 10.1056/NEJMe1414305.

Bedford, T. \& Malik, H. S. (2016) Did a Single Amino Acid Change Make Ebola Virus More Virulent?, Cell, 167(4), pp. 892-894, doi: 10.1016/j.cell.2016.10.032.

Breman, J. G. \& Johnson, K. M. (2014) Ebola then and now, The New England Journal of Medicine, 371(18), pp. 1663-6, doi: 10.1056/NEJMp1410540.

Briand, S., Bertherat, E., P. Cox, P. Formenty, M. P. Kieny, J. K. Myhre, C. Roth, N. Shindo \& C. Dye (2014) The international Ebola emergency, The New England Journal of Medicine, 371(13), pp. 1180-1183, doi: 10.1056/NEJMp1409858.

Brown, C. M. \& DeMaria, A. Jr. (2012) The resurgence of West Nile virus, Annals of Internal Medicine, 157(11), pp. 823-824, doi: 10.7326/0003-4819-157-11-201212040-00543.

Cao-Lormeau, V. M., C. Roche, A. Teissier, E. Robin, A. L. Berry, H. P. Mallet, A. A. Sall \& D. Musso (2014) Zika virus, French polynesia, South pacific, 2013, Emerging Infectious Diseases, 20(6), pp. 1085-1086, doi: 10.3201/eid2006.140138.

Ceccarelli, D., M. Spagnoletti, P. Cappuccinelli, V. Burrus \& M. M. Colombo (2011) Origin of Vibrio cholerae in Haiti, The Lancet. Infectious Diseases, 11(4), pp. 262, doi: 10.1016/S1473-3099(11)70078-0.

Chan, M. (2014) Ebola virus disease in West Africa--no early end to the outbreak, The New England Journal of Medicine, 371(13), pp. 1183-1185, doi: 10.1056/NEJMp1409859.

Chertow, D. S., C. Kleine, J. K. Edwards, R. Scaini, R. Giuliani \& A. Sprecher (2014) Ebola virus disease in West Africa--clinical manifestations and management, The New England Journal of Medicine, 371(22), pp. 2054-2057, doi: 10.1056/NEJMp1413084.

Chin, C. S., J. Sorenson, J. B. Harris, W. P. Robins, R. C. Charles, R. R. Jean-Charles, J. Bullard, D. R. Webster, A. Kasarskis, P. Peluso, E. E. Paxinos, Y. Yamaichi, S. B. Calderwood, J. J. Mekalanos, E. E. Schadt \& M. K. Waldor (2011) The origin of the 
R. B. Roberts: The Ebola Epidemic and Cholera Outbreak and The International Response

Haitian cholera outbreak strain, The New England Journal of Medicine, 364(1), pp. 3342, doi: 10.1056/NEJMoa1012928.

Donnelly, C. A., A. C. Ghani, G. M. Leung, A. J. Hedley, C. Fraser, S. Riley, L. J. AbuRaddad, L. M. Ho, T. Q. Thach, P. Chau, K. P. Chan, T. H. Lam, L. Y. Tse, T. Tsang, S. H. Liu, J. H. Kong, E. M. Lau, N. M. Ferguson \& R. M. Anderson. (2003) Epidemiological determinants of spread of causal agent of severe acute respiratory syndrome in Hong Kong, The Lancet, 361(9371), pp. 1761-1766, doi: 10.1016/S01406736(03)13410-1.

Drain, P. K., Subbaraman, R. \& Heimburger, D. C. (2017) Preserving the Fogarty International Center - Benefits for Americans and the World, The New England Journal of Medicine, 377(1), pp. 9-11, doi: 10.1056/NEJMp1704690.

Farrar, J. J. \& Piot, P. (2014) The Ebola emergency--immediate action, ongoing strategy, The New England Journal of Medicine, 371(16), pp. 1545-1546, doi: 10.1056/NEJMe1411471.

Fauci, A. S. (2014) Ebola--underscoring the global disparities in health care resources, The New England Journal of Medicine, 371(12), pp. 1084-1086, doi: 10.1056/NEJMp1409494.

Fauci, A. S. \& D. M. Morens (2012) The perpetual challenge of infectious diseases, The New England Journal of Medicine 366(5), pp. 454-461, doi: 10.1056/NEJMra1108296.

Glezen, W. P. (2010) How did the 2008-2009 seasonal influenza vaccine affect the pandemic?" Clinical Infectious Diseases, 51(12), pp. 1380-2, doi: 10.1086/657312.

Ivers, L. C (2017) Eliminating Cholera Transmission in Haiti, The New England Journal of Medicine, 376(2), pp. 101-103, doi: 10.1056/NEJMp1614104.

Katz, I. T. \& Wright, A. A. (2017) Scientific Drought, Golden Eggs, and Global Leadership - Why Trump's NIH Funding Cuts Would Be a Disaster, The New England Journal of Medicine, 376(18), pp. 1701-1704, doi: 10.1056/NEJMp1703734.

Katz, J. M. (2016) Facing Stern Report, U.N. Admits role in Cholera Outbreak in Haiti, The New York Times, August 17, 2016, Americas, available at: https://www.nytimes.com/2016/08/18/world/americas/united-nations-haiti-cholera.html (October 17, 2017).

Ledgerwood, J. E., A. D. DeZure, D. A. Stanley, E. E. Coates, L. Novik, M. E. Enama, N. M. Berkowitz, Z. Hu, G. Joshi, A. Ploquin, S. Sitar, I. J. Gordon, S. A. Plummer, L. A. Holman, C. S. Hendel, G. Yamshchikov, F. Roman, A. Nicosia, S. Colloca, R. Cortese, R. T. Bailer, R. M. Schwartz, M. Roederer, J. R. Mascola, R. A. Koup, N. J. Sullivan, B. S. Graham, and V. R. C. Study Team (2017) Chimpanzee Adenovirus Vector Ebola Vaccine, The New England Journal of Medicine, 376(10), pp. 928-938, doi: 10.1056/NEJMoa1410863.

Luquero, F. J., M. Rondy, J. Boncy, A. Munger, H. Mekaoui, E. Rymshaw, A. L. Page, B. Toure, M. A. Degail, S. Nicolas, F. Grandesso, M. Ginsbourger, J. Polonsky, K. P. Alberti, M. Terzian, D. Olson, K. Porten \& I. Ciglenecki (2016) Mortality Rates during Cholera Epidemic, Haiti, 2010-2011, Emerging Infectious Diseases, 22(3), pp. 410-416, doi: 10.3201/eid2203.141970.

Mari Saez, A., S. Weiss, K. Nowak, V. Lapeyre, F. Zimmermann, A. Dux, H. S. Kuhl, M. Kaba, S. Regnaut, K. Merkel, A. Sachse, U. Thiesen, L. Villanyi, C. Boesch, P. W. Dabrowski, A. Radonic, A. Nitsche, S. A. Leendertz, S. Petterson, S. Becker, V. Krahling, E. Couacy-Hymann, C. Akoua-Koffi, N. Weber, L. Schaade, J. Fahr, M. Borchert, J. F. Gogarten, S. Calvignac-Spencer \& F. H. Leendertz (2015) Investigating the zoonotic origin of the West African Ebola epidemic, EMBO Molecular Medicine, 7(1), pp. 17-23, doi: 10.15252/emmm.201404792. 
Morens, D. M., Folkers, G. K. \& Fauci, A. S. (2008) Emerging infections: a perpetual challenge, The Lancet. Infectious Diseases, 8(11), pp. 710-719, doi: 10.1016/S14733099(08)70256-1.

Mugele, J. \& Priest, C. (2014) A good death---Ebola and sacrifice, The New England Journal of Medicine, 371(13), pp. 1185-11877, doi: 10.1056/NEJMp1410301.

Pape, J. W., Johnson, W. D. Jr. \& Fitzgerald, D. W. (2010) The earthquake in Haiti--dispatch from Port-au-Prince, The New England Journal of Medicine, 362(7), pp. 575-577, doi: 10.1056/NEJMp1001015.

Pape, J. W. \& Rouzier, V. (2014) Embracing oral cholera vaccine--shifting response to cholera, The New England Journal of Medicine, 370(22), pp. 2067-2069, doi: 10.1056/NEJMp1402837.

Paules, C. I. \& Fauci, A. S. (2017) Yellow Fever - Once Again on the Radar Screen in the Americas, The New England Journal of Medicine, 376(15), pp. 1397-1399, doi: 10.1056/NEJMp1702172.

Petersen, L. R., Jamieson, D. J., Powers, A. M. \& Honein, M. A. (2016) Zika Virus, The New England Journal of Medicine, 374(16), pp. 1552-1563, doi: 10.1056/NEJMra1602113.

Piarroux, R., R. Barrais, B. Faucher, R. Haus, M. Piarroux, J. Gaudart, R. Magloire \& D. Raoult. (2011) Understanding the cholera epidemic, Haiti, Emerging Infectious Diseases, 17(7), pp. 1161-1168, doi: 10.3201/eid1707.110059.

Quammen, D. (2014) Ebola. The Natural and Human History of a Deadly Virus (500 Fifth Avenue, New York, NY: W.W. Norton \& Company, Inc.).

Regules, J. A., J. H. Beigel, K. M. Paolino, J. Voell, A. R. Castellano, Z. Hu, P. Munoz, J. E. Moon, R. C. Ruck, J. W. Bennett, P. S. Twomey, R. L. Gutierrez, S. A. Remich, H. R. Hack, M. L. Wisniewski, M. D. Josleyn, S. A. Kwilas, N. Van Deusen, O. T. Mbaya, Y. Zhou, D. A. Stanley, W. Jing, K. S. Smith, M. Shi, J. E. Ledgerwood, B. S. Graham, N. J. Sullivan, L. L. Jagodzinski, S. A. Peel, J. B. Alimonti, J. W. Hooper, P. M. Silvera, B. K. Martin, T. P. Monath, W. J. Ramsey, C. J. Link, H. C. Lane, N. L. Michael, R. T. Davey, Jr., S. J. Thomas \& VSVDeltaG-Zebov- G. P. Study Group r. (2017) A Recombinant Vesicular Stomatitis Virus Ebola Vaccine, The New England Journal of Medicine, 376(4), pp. 330-341, doi: 10.1056/NEJMoa1414216.

Roberts, R. B. (2017) CEPI - A global partnership, Germs, 7(1), pp. 8-9, doi: 10.18683/germs.2017.1102.

Sands, P., Mundaca-Shah, C. \& Dzau, V. J. (2016) The Neglected Dimension of Global Security--A Framework for Countering Infectious-Disease Crises, The New England Journal of Medicine, 374(13), pp. 1281-1287, doi: 10.1056/NEJMsr1600236.

Schieffelin, J. S., J. G. Shaffer, A. Goba, M. Gbakie, S. K. Gire, A. Colubri, R. S. Sealfon, L. Kanneh, A. Moigboi, M. Momoh, M. Fullah, L. M. Moses, B. L. Brown, K. G. Andersen, S. Winnicki, S. F. Schaffner, D. J. Park, N. L. Yozwiak, P. P. Jiang, D. Kargbo, S. Jalloh, M. Fonnie, V. Sinnah, I. French, A. Kovoma, F. K. Kamara, V. Tucker, E. Konuwa, J. Sellu, I. Mustapha, M. Foday, M. Yillah, F. Kanneh, S. Saffa, J. L. Massally, M. L. Boisen, L. M. Branco, M. A. Vandi, D. S. Grant, C. Happi, S. M. Gevao, T. E. Fletcher, R. A. Fowler, D. G. Bausch, P. C. Sabeti, S. H. Khan, R. F. Garry, K. G. H. Lassa Fever Program, Consortium Viral Hemorrhagic Fever \& W. H. O. Clinical Response Team (2014) Clinical illness and outcomes in patients with Ebola in Sierra Leone, The New England Journal of Medicine, 371(22), pp. 2092-2100, doi: 10.1056/NEJMoa1411680.

Staples, J. E. \& Fischer, M. (2014) Chikungunya virus in the Americas--what a vectorborne pathogen can do, The New England Journal of Medicine, 371(10), pp. 887-889, doi: 10.1056/NEJMp1407698. 
R. B. Roberts: The Ebola Epidemic and Cholera Outbreak and The International Response

Talkington, D., C. Bopp, C. Tarr, M. B. Parsons, G. Dahourou, M. Freeman, K. Joyce, M. Turnsek, N. Garrett, M. Humphrys, G. Gomez, S. Stroika, J. Boncy, B. Ochieng, J. Oundo, J. Klena, A. Smith, K. Keddy \& P. Gerner-Smidt (2011) Characterization of toxigenic Vibrio cholerae from Haiti, 2010-2011, Emerging Infectious Diseases, 17(11), pp. 2122-2129, doi: 10.3201/eid1711.110805.

Team, W. H. O. Ebola Response, B. Aylward, P. Barboza, L. Bawo, E. Bertherat, P. Bilivogui, I. Blake, R. Brennan, S. Briand, J. M. Chakauya, K. Chitala, R. M. Conteh, A. Cori, A. Croisier, J. M. Dangou, B. Diallo, C. A. Donnelly, C. Dye, T. Eckmanns, N. M. Ferguson, P. Formenty, C. Fuhrer, K. Fukuda, T. Garske, A. Gasasira, S. Gbanyan, P. Graaff, E. Heleze, A. Jambai, T. Jombart, F. Kasolo, A. M. Kadiobo, S. Keita, D. Kertesz, M. Kone, C. Lane, J. Markoff, M. Massaquoi, H. Mills, J. M. Mulba, E. Musa, J. Myhre, A. Nasidi, E. Nilles, P. Nouvellet, D. Nshimirimana, I. Nuttall, T. Nyenswah, O. Olu, S. Pendergast, W. Perea, J. Polonsky, S. Riley, O. Ronveaux, K. Sakoba, R. Santhana Gopala Krishnan, M. Senga, F. Shuaib, M. D. Van Kerkhove, R. Vaz, N. Wijekoon Kannangarage \& Z. Yoti. (2014) Ebola virus disease in West Africa--the first 9 months of the epidemic and forward projections, The New England Journal of Medicine, 371(16), pp. 1481-95, doi: 10.1056/NEJMoa1411100.

Waldor, M. K., Hotez, P. J. \& Clemens, J. D. (2010) A national cholera vaccine stockpile--a new humanitarian and diplomatic resource, The New England Journal of Medicine, 363(24), pp. 2279-2282, doi: 10.1056/NEJMp1012300.

Walt, V. (2014) WHO Chief Says Ebola Response 'Did Not Match' Scale of the Outbreak, Time Health, October 30, 2014, available at: http://time.com/3548096/ebola-worldhealth-organization-margaret-chan/ (October 17, 2017)

Walton, D. A. \& Ivers, L. C. (2011) Responding to cholera in post-earthquake Haiti, The New England Journal of Medicine, 364(1), pp. 3-5, doi: 10.1056/NEJMp1012997.

Weaver, S. C. \& Lecuit, M. (2015) Chikungunya virus and the global spread of a mosquitoborne disease, The New England Journal of Medicine, 372(13), pp. 1231-1239, doi: 10.1056/NEJMra1406035. 